\title{
Osteoporosis dan Osteodistrofi pada Anak
}

\author{
Frida Soesanti \\ Departemen Ilmu Kesehatan Anak Fakultas Kedokteran Universitas Indonesia-RS Ciptomangunkusumo, Jakarta
}

\begin{abstract}
Osteoporosis anak saat ini merupakan salah satu kelainan penting yang melibatkan hampir semua subspesialisasi. Berbeda dengan definisi osteoporosis pada orang dewasa, diagnosis osteoporosis pada anak tidak hanya ditentukan oleh densitas mineral tulang yang diukur dengan DXA (dual energy X-ray absorptiometry). Osteoporosis primer terjadi akibat kelainan genetik, misalnya osteogenesis imperfecta dan osteoporosis juvenil idiopatik. Osteoporosis disebut sekunder jika timbul akibat penyakit kronik yang mendasari atau terapi penyakit tersebut. Kemajuan teknologi kedokteran meningkatkan survival anak-anak dengan penyakit kronik atau penyakit yang mengancam nyawa. Banyak terapi medikamentosa ini memiliki efek jangka panjang pada tubuh, termasuk osteoporosis. Disfungsi endokrin, imobilitas, faktor nutrisi, penyakit kronik dan kondisi inflamasi kronik memengaruhi terjadinya osteoporosis sekunder pada anak. Pada anak dengan penyakit ginjak kronik, terjadi gangguan metabolism tulang, remodeling and modelling tulang yang menyebabkan suatu kondisi yang disebut dengan chronic kidney disease-mineral bone disorders (CKD-MBD), termasuk di dalamnya adalah osteodistrofi renal. Terapi osteoporosis pada anak masih merupakan suatu tantangan tersendiri. Tata laksana terbaik pada osteoporosis sekunder dan CKD-MBD adalah pencegahan. Deteksi dini kemungkinan terjadinya gangguan metabolisme tulang dan osteoporosis penting untuk mengoptimalkan kesehatan tulang anak, mencegah osteoporosis dan kemungkinan fraktur, yang pada akhirnya mengoptimalkan pertumbuhan dan perkembangan anak. Sari Pediatri 2019;21(2):138-44
\end{abstract}

Kata kunci: osteoporosis, osteodistrofi, tulang

\section{Osteoporosis and Osteodystrophy in Children}

Frida Soesanti

Pediatric osteoporosis has become an emerging issue worldwide and has become an important pediatric disorder that involves almost all pediatric subspecialties. In contrast to those of adults, diagnosis of osteoporosis in pediatric population is not exclusively based on bone mineral density (BMD) measured by DXA (dual energy X-ray absorptiometry). Osteoporosis considered being primary if occurs due to genetic factors. Osteogenesis imperfecta and idiopathic juvenile osteoporosis are the best examples of primary osteoporosis. Osteoporosis is defined as secondary if occurs due to other underlying illness or its treatment. Advances in health technology with the discovery and development of some drugs have increased the survival of children suffered from life threatening and chronic illnesses. Many of these drugs have long-term effect to our body, including osteoporosis. Factors associated with secondary osteoporosis include endocrine dysfunction, immobility, nutritional factors, and chronic illness or chronic inflammatory conditions. In children with chronic kidney diseases, alteration in bone metabolism and bone modeling and remodeling result in chronic kidney disease-mineral bone disorders (CKD-MBD), including renal osteodystrophy. Treatment of pediatric osteoporosis and CKD-MBD remains a challenge. Revisiting of these issues, the best management of secondary osteoporosis and CKD-MBD is prevention. Early recognition and anticipation of the potential skeletal risk in many of pediatric illness will preserve the bone health of our children, future fractures and will optimize the growth and development of those with chronic conditions. Sari Pediatri 2019;21(2):138-44

Keyword: osteoporosis, osteodistrofi, bone

Alamat korespondensi: Frida Soesanti. Departemen Ilmu Kesehatan Anak, Fakultas Kedokteran Universitas Indonesia-RS Ciptomangunkusumo, Jakarta. Email: fsoesanti@gmail.com 
S elama ini osteoporosis dianggap sebagai penyakit akibat proses penuaan. ${ }^{1}$ Namun, saat ini makin banyak osteoporosis yang ditemukan pada anak dan remaja. Diagnosis osteoporosis pada anak dan remaja lebih sulit daripada diagnosis osteoporosis pada dewasa. ${ }^{1}$ Pada dewasa, dikenal adanya osteopenia dan osteoporosis yang digunakan untuk menunjukkan berkurangnya massa tulang, abnormalitas mikroarsitektur tulang dan berkurangnya kekuatan tulang sehingga meningkatkan risiko terjadinya fraktur. ${ }^{2}$ Pada dewasa, WHO mendefinisikan osteopenia sebagai skor T BMD (bone mineral density) yang diperiksa dengan dual energy X-ray absorptiometry (DXA) antara -1,1 sampai -2,4 SD; sedangkan osteoporosis jika skor T pada BMD $\leq-2,5$ SD. ${ }^{2}$ Namun tidak demikian dengan anak. Pada anak tidak digunakan pengertian osteopenia dan tidak digunakan parameter skor $T$ pada pemeriksaan BMD melainkan skor Z. ${ }^{1,3}$

Osteoporosis pada anak dan remaja akan sangat berpengaruh pada kekuatan tulang karena perkembangan tulang pada masa anak dan remaja ini penting untuk mencapai puncak densitas tulang atau peak bone mass yang akan menentukan kekuatan tulang dikemudian hari. ${ }^{1}$ Meningkatnya teknologi kesehatan menyebabkan angka survival anak dan remaja dengan penyakit kronik meningkat. Namun, beberapa obat atau terapi tersebut menimbulkan efek samping jangka panjang terhadap kesehatan tulang yang dapat mempengaruhi kualitas hidup. ${ }^{4}$ Lebih lanjut dalam makalah ini akan dibahas mengenai osteoporosis sekunder dan osteodistrofi renal yang terjadi pada anak dan remaja.

\section{Normal bone bealth}

Tulang dalam tubuh terdiri atas tulang panjang dan tulang pipih. Pada anak yang masih tumbuh maka yang bertambah panjang adalah tulang panjang, bukan tulang pipih. ${ }^{2}$ Tulang panjang dibagi atas bagian diafisis, metafisis, lempeng epifisis (growth plate), dan epifisis (Gambar 1). Komposisi tulang itu terdiri atas sel-sel tulang (seperti osteoblas, osteoklas, osteosit), bagian mineral (kristal hidroksiapatit), dan matriks ekstraseluler (jaringan kolagen dan jaringan non kolagen). Jaringan kolagen (tipe I, II, V) ini dihasilkan oleh osteoblas dan merupakan tempat deposisi kristal hidroksiapatit. $^{2}$

Massa tulang ditentukan oleh proses modeling dan remodeling, sedangkan kekuatan tulang ditentukan

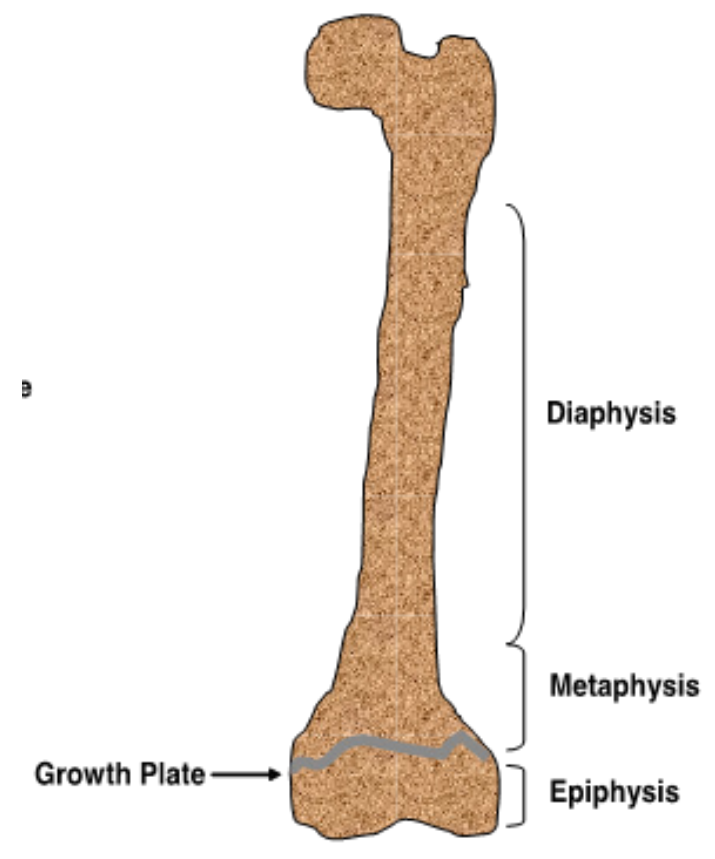

Gambar 1. Tulang panjang

oleh ukuran dan massa mineral, mikroarsitektur dan makroarsitektur serta elastisitas kolagen yang diregulasi oleh hormon dan growth factors, dan kekuatan mekanik tulang yang didapat dari faktor lingkungan (gravitasi) dan sistem muskuler. ${ }^{2,5}$ Faktor genetik memiliki peran besar dalam tercapainya peak bone mass atau puncak kepadatan tulang (sekitar 80\%) sedangkan sisanya dipengaruhi oleh faktor lingkungan, seperti hormonal, nutrisi, mobilitas, dan penyakit kronik yang mendasari (20\%). ${ }^{2,5}$ Tulang mulai dibentuk (modeling) pada awal kehamilan dan terus bertambah dengan adanya proses remodelling.

Fungsi struktural dan metabolik tulang memerlukan koordinasi interaksi antara osteoblas dan osteoklas serta berbagai faktor lainnya baik lokal maupun sistemik. Osteoblas mensintesis kolagen, alkali fosfatase, dan osteokalsin. ${ }^{2,5}$ Hormon paratiroid, kalsitriol, glukokortikoid, hormon seks, hormon pertumbuhan (growth hormone/GH), dan hormon tiroid juga mempengaruhi modeling tulang melalui efeknya terhadap osteoblas. Hasil modeling tulang menyebabkan pertumbuhan dan perubahan pada bentuk tulang. Pertumbuhan linear pada masa anak dan remaja terjadi karena pertumbuhan kartilago pada lempeng epifisis tulang panjang yang dilanjutkan dengan pembentukan tulang endokondral. ${ }^{2,5}$ Selama pubertas dan awal 
kehidupan dewasa, deposisi endosteal dan penebalan trabekular menghasilkan massa dan kekuatan tulang yang maksimal. Modeling tulang ini dilanjutkan dengan proses remodeling tulang. ${ }^{2,5}$

Remodeling tulang merupakan suatu proses kontinu yang terjadi secara siklik dimana tulang yang telah dibentuk secara periodik akan diresorpsi dan digantikan dengan tulang baru. Setiap siklus remodeling berlangsung antara 90-120 hari. ${ }^{2}$ Proses remodeling ini memungkinkan struktur dan kekuatan tulang terus diperbarui. Proses remodeling ini memerlukan interaksi osteoblas dan osteoklas. Remodeling tulang terdiri atas empat fase, yaitu fase aktivasi fungsi osteoklas, dilanjutkan dengan fase resorpsi tulang, kemudian fase reversal di mana osteoblas dan osteosit teraktivasi dan diakhiri dengan fase pembentukan tulang baru. ${ }^{2}$

\section{Osteoporosis pada anak}

\section{Definisi}

Berbeda dengan dewasa maka pada anak tidak digunakan definisi osteopenia. Diagnosis osteoporosis pada anak jauh lebih sulit daripada dewasa. Jika diagnosis osteoporosis pada dewasa semata-mata didasarkan pada hasil pengukuran BMD, maka tidak demikian halnya dengan anak. International Society of Clinical Densitometry (ISCD), $2013^{3}$ menyatakan bahwa diagnosis osteoporosis pada anak ditegakkan jika ditemukan adanya fraktur kompresi vertebra (satu atau lebih fraktur kompresi vertebra) tanpa adanya trauma bermakna atau kelainan yang mendasarinya di vertebra, atau jika tanpa fraktur kompresi vertebra maka osteoporosis pada anak ditegakkan jika memenuhi kriteria berikut ini:

- Nilai skor Z BMD $\leq-2,0 \mathrm{SD}$, dan

- Adanya riwayat fraktur yang bermakna, yaitu

- dua atau lebih fraktur tulang panjang pada usia 10 tahun,

- atau tiga atau lebih fraktur tulang panjang pada usia berapapun sampai usia 19 tahun.

\section{Klasifikasi}

The International Society of Clinical Densitometry ${ }^{3}$ membagi osteoporosis pada anak menjadi osteoporosis primer dan sekunder. Disebut osteoporosis primer jika terjadi primer pada anak tanpa ada penyakit lain yang mendasarinya. Osteoporosis primer ini terutama disebabkan oleh faktor genetik. Osteoporosis primer ini, antara lain, osteogenesis imperfekta dan idiopathic juvenile osteoporosis. Mutasi gen COL1A1 atau COL1A2 yang mengode kolagen tipe 1 merupakan penyebab beberapa tipe osteogenesis imperfekta. Gen lain yang juga berperan dalam terjadinya osteogenesis imperfekta adalah CRTAP dan SERPINF1. ${ }^{2}$

Osteoporosis dikatakan sebagai sekunder jika osteoporosis timbul akibat adanya penyakit lain yang mendasarinya atau akibat terapi lain. ${ }^{4,6,7}$ Kemajuan teknologi dibidang kesehatan dengan temuan dan pengembangan berbagai macam obat dan teknologi baru telah mampu meningkatkan survival anak dengan penyakit kronik atau penyakit yang mengancam nyawa. Tidak jarang obat-obatan ini memiliki efek jangka panjang terhadap tubuh, termasuk meningkatkan risiko terjadinya osteoporosis. ${ }^{4}$ Faktor yang meningkatkan terjadinya osteoporosis sekunder meliputi gangguan fungsi endokrin, imobilitas, faktor nutrisi, dan kondisi inflamasi kronik atau penyakit kronik lainnya. ${ }^{4,6,7}$

\section{Osteoporosis sekunder}

Prevalens osteoporosis sekunder bervariasi berdasarkan penyakit yang mendasarinya, baik dari durasi, derajat keparahan dan juga terapinya. Banyak faktor yang berperan terhadap timbulnya osteoporosis pada penyakit kronik termasuk berkurangnya mobilitas, disfungsi endokrinologis, faktor nutrisi, dan iatrogenik akibat efek samping terapi. ${ }^{4,6,7}$

\section{Endokrinologis}

Beberapa hormon seperti steroid seks, GH, dan IGF1 mempengaruhi bone turnover dan akrual massa tulang. ${ }^{4}$ Pubertas terlambat atau pubertas yang terhenti menyebabkan menurunnya BMD dan meningkatnya risiko fraktur. Penyakit kronik dan terapi yang diberikan untuk penyakit kronik tersebut dapat menyebabkan pubertas terlambat. Hormon pubertas penting untuk perkembangan skeletal normal dan tercapainya puncak kepadatan massa tulang. ${ }^{4,6,7}$ Hiperparatiroidisme primer menstimulasi resorpsi tulang dan menyebabkan kehilangan tulang. Hipertiroidisme, hiperkortisolisme dan diabetes melitus juga memiliki efek samping terhadap skeletal. . $^{4}$

\section{Immobilitas}

Tanpa adanya loading tulang dan mobilitas yang adekuat, massa tulang akan menurun dengan cepat. 
Anak dengan ambulasi yang terbatas akibat palsi serebral, Duchene muscular dystrophy, spinal muscular atrophy atau kelainan neuromuskeler lainnya seringkali memiliki massa tulang yang rendah dan fraktur. ${ }^{4,6,7}$ Lokasi fraktur yang paling sering adalah ekstremitas bawah, terutama femur. Fraktur kompresi vertebra terjadi pada $25 \%$ pasien dengan disabilitas motor. ${ }^{4}$

\section{Faktor nutrisi}

Faktor nutrisi yang penting bagi tulang adalah vitamin D dan kalsium. ${ }^{4,8}$ Asupan kalsium dan vitamin yang cukup, penting untuk mineralisasi tulang. ${ }^{4,8}$ Beberapa nutrisi lainnya seperti protein, magnesium, fosfor, kalium, fluor, besi, mangan, zinc, vitamin A, K, C juga diperlukan untuk formasi tulang. ${ }^{4,6,7}$ Gangguan makan seperti anoreksia nervosa atau malabsorpsi biasanya menyebabkan gangguan nutrisi, termasuk defisiensi protein, lemak, vitamin larut dalam lemak, dan kalsium yang menyebabkan kehilangan massa tulang.

\section{Iatrogenik: osteoporosis akibat glukokortikoid}

Glukokortikoid banyak digunakan pada anak karena efek anti inflamasi dan efek imunosupresi yang dimiliki oleh glukokortikoid. ${ }^{1,4,6,7,9}$ Berbagai preparat glukokortikoid juga digunakan sebagai salah satu agen kemoterapi berbagai kanker pada anak dan untuk mengontrol penyakit autoimun sistemik seperti lupus eritematosus atau inflammatory bowel disease. Glukokortikoid juga digunakan untuk terapi alergi dan asma dalam praktek sehari-hari, namun tidak jarang penggunaannya menjadi berlebihan dan terkesan irasional. ${ }^{1,4,7,9}$

Glukokortikoid memiliki efek samping baik langsung maupun tidak langsung terhadap skeletal, yang terjadi dalam dua fase. Fase awal adalah meningkatnya resorpsi tulang yang disebabkan oleh meningkatnya survival osteoklas. Pada tahap ini, meningkatnya resorpsi tulang disebabkan oleh efek tidak langsung glukokortikoid yang menyebabkan menurunnya absorpsi kalsium di intestinal, meningkatkan kalsiuria, dan menurunkan sintesis gonadotropin, steroid seks, dan IGF-1. Tahap selanjutnya glukokortikoid akan menginduksi apoptosis osteoblas matur dan osteosit yang akan mengurangi formasi tulang. . $^{1,4,7,9}$

Penelitian pada dewasa menunjukkan bahwa terapi glukokortikoid adalah penyebab osteoporosis sekunder yang paling sering ditemukan. Fraktur vertebra terjadi pada $30-50 \%$ pasien yang mendapatkan terapi glukokortikoid jangka panjang. ${ }^{4,9}$ Fraktur vertebra merupakan lokasi fraktur yang paling sering pada osteoporosis akibat glukokortikoid. Pada pasien dengan osteoporosis yang diinduksi oleh glukokortikoid, kehilangan densitas tulang bersifat bifasik, terjadi secara cepat (6-12\%) dalam tahun pertama dan selanjutnya lebih lambat (3\% per tahun). Risiko fraktur setinggi $75 \%$ dalam 3 bulan setelah awal terapi saat belum terdapat penurunan densitas mineral. ${ }^{4,9} \mathrm{Hal}$ ini menunjukkan bahwa efek simpang glukokortikoid terhadap tulang yang tidak dapat dipantau dengan pemeriksaan densitas tulang.

Studi kohort pada orang dewasa, terapi prednison dengan dosis $10 \mathrm{mg}$ per hari selama lebih dari 90 hari meningkatkan risiko fraktur sebesar tujuh kali lipat dan meningkatkan risiko fraktur vertebra sebesar 17 kali lipat. Penelitian pada dewasa menunjukkan bahwa besarnya efek glukokortikoid pada tulang dipengaruhi oleh dosis yang digunakan (dose dependent). Dosis prednisolon sebesar $0,62 \mathrm{mg} / \mathrm{kg} /$ hari pada anak dengan juveline idiopatik artritis dihubungkan dengan terjadinya fraktur kompresi vertebra dalam 2,6 tahun. ${ }^{9}$ Penggunaan steroid intermiten juga menjadi faktor predisposisi terjadinya fraktur. Pada studi kasus kontrol yang melibatkan 37.000 anak yang mendapat glukokortioid oral sebanyak tiga atau empat seri pemberian dengan rerata durasi terapi selama 6,4 hari didapatkan bahwa anak yang mendapat glukokortikoid memiliki risiko 1,32 kali lipat untuk mengalami fraktur dibandingkan kontrol (95\% interval kepercayaan 1,031,69). ${ }^{1}$ Berbeda dengan dewasa, saat ini masih belum terdapat data tentang dosis glukokortikoid yang aman untuk anak. ${ }^{1}$

\section{Penyakit rheumatoid}

Anak penyakit rheumatik memiliki risiko mengalami osteoporosis akibat beberapa faktor yang berhubungan penyakit dasarnya maupun terapi yang diberikan, termasuk penggunaan glukokortikoid, disfungsi endokrin yang menyebabkan keterlambatan pertumbuhan dan pubertas, defisiensi nutrisi, berkurangnya aktivitas yang weight-bearing (menahan berat) dan inflamasi kronik yang mengganggu keseimbangan antara formasi dan resorpsi tulang. ${ }^{4,6,7,10}$ Pasien dengan lupus eritematosus sistemik (juvenile onset) lebih rentan untuk mengalami penurunan BMD dan osteoporosis. Faktor yang bertanggung jawab terhadap efek ini adalah berbagai macam sitokin dan penggunaan glukokortikoid, terutama melalui sistem RANK-RANKL-OPG. ${ }^{4,6,7,10,11}$ Compeyrot-Lacassagne $\mathrm{dkk}^{12}$ mendeskripsikan bahwa 
prevalens osteoporosis pada lupus eritematosus sistemik adalah sebesar 20,3. Henderson $\mathrm{dkk}^{13}$ menemukan skor BMD yang rendah (skor $Z<-1$ SD) pada 29,2\% pasien Juvenile rheumatoid arhtritis (JRA) prepubertal dan pascapubertal. Tidak ada pasien JRA pada penelitian Henderson dkk yang menerima glukokortikoid. Pasien dengan penyakit yang lebih berat dan petanda inflamasi yang lebih berat rentan untuk mengalami osteoporosis. Pada penyakit rheumatoid ini, interleukin 6 merupakan sitokin yang berperan penting dalam terjadinya penurunan massa tulang dengan menstimulasi aktivitas osteoklas seperti yang ditunjukkan dengan penelitian pada model interleukin-6-transgenic mice. ${ }^{1,11}$

\section{Penyakit hematologi-onkologi}

Anak dengan keganasan mengalami penurunan massa tulang akibat penggunaan glukokortikoid maupun akibat leukemianya sendiri (infiltrasi leukemia). Anak dengan leukemia limfoblastik akut memiliki risiko lebih tinggi untuk terjadinya fraktur saat diagnosis, terapi, maupun sesudah terapi. ${ }^{4}$ Selama 12 bulan penelitian prospektif terhadap anak dengan ALL, 16\% dari 155 anak mengalami fraktur vertebra dan probabilitas insiden fraktur juga meningkat selama satu tahun setelah terapi. ${ }^{4}$

Pada talasemia, patogenesis penurunan massa tulang bersifat multifaktorial. Pada talasemia beberapa faktor yang menyebabkan terjadinya osteoporosis antara lain adalah faktor endokrin termasuk keterlambatan maturasi seksual, diabetes melitus, hipotiroidisme, defisiensi growth hormone atau disfungsi kelenjar paratiroid, faktor peningkatan hematopoesis dan ekspansi progresif sumsum tulang, serta efek toksisitas langsung besi terhadap osteoblas. ${ }^{4}$

\section{Tata laksana}

Tata laksana osteoporosis sekunder pada anak meliputi terapi farmakologis dan non farmakologis. Terapi farmakologis yang penting antara lain adalah aktivitas fisik untuk meningkatkan loading mekanik tulang. ${ }^{4}$ Latihan fisik ini harus dilakukan secara terarah. Pada anak dengan keterbatasan fisik seperti anak dengan palsi serebral spastis yang tidak memungkinkan aktivitas fisik yang biasa maka fisioterapi terbukti berguna untuk meningkatkan kekuatan tulang. , 7,13

Faktor nutrisi juga perlu ditata laksana secara adekuat. Defisiensi vitamin D harus diidentifikasikan dan dikoreksi pada anak dengan tersangka osteoporosis. Defisit nutrisi lain termasuk asupan nutrisi yang tidak adekuat atau meningkatnya kehilangan kalsium dan protein harus dikoreksi dengan modifikasi diet atau suplementasi. ${ }^{4,7,13}$

Sampai saat ini, pilihan terapi farmakologis yang tersedia untuk osteoporosis pada anak sangat terbatas. Bisfosfonat merupakan satu-satunya farmakologis yang penggunaannya pada populasi anak sudah banyak diteliti. Bisfosfonat intravena merupakan pilihan utama terapi pada anak dengan osteogenesis imperfekta. 4,7,13,14 Namun, efektivitas dan keamanan bisfosfonat pada anak dengan osteoporosis sekunder masih belum diketahui dengan pasti. Review sistematik tentang efikasi bisfosfonat pada JRA menyimpulkan bahwa meskipun terapi tersebut dapat membantu pasien dengan penurunan densitas tulang dan fraktur namun kualitas penelitian yang ada masih bervariasi sehingga belum ada rekomendasi universal tentang penggunaan bisfosfonat sistemik pada pasien palsi serebral. $4,7,13,14$

Penelitian yang melibatkan 20 anak dengan palsi serebral dengan penurunan densitas tulang yang diinduksi oleh steroid, atau kondisi lainnya dihubungkan dengan osteoporosis sekunder menunjukkan efek yang positif terapi zoledronic acid IV terhadap densitas tulang, turnover tulang dan arsitekstur tulang. Cochrane review pada anak dengan osteoporosis sekunder menyimpulkan bahwa sampai saat ini data yang ada tidak cukup untuk mendukung penggunaan bisfosfonat sebagai terapi standar pada osteoporosis sekunder. ${ }^{4,713,14}$ Mengingat semua data yang ada maka tata laksana terbaik dari osteoporois adalah preventif. Deteksi dini dan antisipasi adanya risiko skeletal pada berbagai penyakit pada anak akan menjamin kesehatan tulang bagi anak dan remaja dan mengoptimalkan pertumbuhan dan perkembangan anak dan remaja dengan kondisi kronik.

\section{Osteodistrofi renal}

\section{Definisi}

Pada anak, penyakit ginjal kronik dapat menyebabkan gangguan regulasi metabolisme mineral, gangguan pada proses modeling-remodeling tulang dan gangguan pertumbuhan. ${ }^{15-17}$ Gagal tumbuh dan perawakan pendek pada anak dengan penyakit ginjal kroniknya biasanya cukup jelas sehingga sering menjadi perhatian pasien, keluarga dan dokter. Pada penyakit ginjal kronik, kelainan metabolisme tulang dan mineral 
akibat kelainan ginjal ini disebut dengan chronic kidney disease-mineral and bone disorder (CKD-MBD). ${ }^{15-17}$ Manifestasi CKD-MBD meliputi salah satu atau kombinasi dari berikut kriteria berikut ini:

- adanya abnormalitas kalsium, fosfor, hormon paratiroid (HPT) dan vitamin D

- adanya abnormalitas histologi tulang, pertumbuhan linear atau kekuatan tulang

- adanya kalsifikasi sistem vaskuler atau kalsifikasi jaringan lunak lainnya.

Osteodistrofi renal adalah istilah spesifik yang digunakan untuk menggambarkan kelainan tulang yang timbul sebagai komplikasi penyakit ginjal kronik dan merupakan salah satu bagian dari CKD-MBD. Osteodistrofi renal ditandai dengan laju remodeling tulang yang tinggi (meningkatnya laju resorpsi dan formasi tulang) akibat hiperparatiroidisme sekunder. ${ }^{15-17}$

\section{Patogenesis}

Pada saat laju filtrasi glomerular menurun menjadi kurang dari 30\% normal maka ekskresi fosfat terganggu menyebabkan akumulasi fosfat intraseluler dan ekstraseluler, hiperfosfatemia, dan hipokalsemia. Kondisi ini menyebabkan terjadinya peningkatan sekresi hormon paratiroid (hiperparatiroidisme sekunder). ${ }^{15-17}$ Lebih lanjut lagi, down-regulation ekspresi calsium sensing reseptor (CaSR) pada kelenjar paratiroid yang uremik menyebabkan terjadinya hiperplasia sel kelenjar paratiroid dan meningkatkan sekresi hormon paratiroid. Penurunan sintesis kalsitriol oleh ginjal juga berperan terhadap terjadinya hiperparatiroidisme sekunder. Peningkatan sekresi hormon paratiroid akibat hiperparatiroidisme sekunder dan meningkatnya berbagai sitokin inflamasi meningkatkan laju turnover tulang dan laju resorpsi tulang. Pada penyakit ginjal kronik, skeletal menjadi relatif insensitif terhadap hormon paratiroid. Asidosis kronik juga berperan dalam proses demineralisasi tulang. Kesemua faktor ini berperan terhadap timbulnya osteodistrofi renal pada penyakit ginjal kronik. ${ }^{15-17}$

Setelah transplantasi ginjal, hiperparatiroidisme sekunder dapat menetap beberapa bulan atau tahun setelah transplantasi ginja. Intensitas dan lamanya hiperparatiroidisme sekunder ini menunjukkan derajat berat dan durasi penyakit ginjal kronik sebelum transplantasi ginjal. Pada penelitian yang melibatkan 47 anak resipien transplan ginjal, pada 3 tahun pasca transplantasi ditemukan bahwa sebanyak 65\% anak menunjukkan turn over tulang normal sedangkan pada 25\% kasus ditemukan hiperparatiroidisme sekunder ringan dan pada $10 \%$ kasus ditemukan kondisi penyakit tulang adinamik ${ }^{15-17}$

\section{Manifestasi klinis, laboratoris, dan radiologis}

Osteodistrofi renal pada anak dapat tanpa gejala kecuali gangguan pertumbuhan linear. Makin lanjut penyakitnya maka dapat terjadi deformitas ekstremitas, slipped ephyphiseal, fraktur, nyeri tulang dan sendi, serta timbul kelemahan otot. ${ }^{15-17}$

Secara biokimia osteodistrofi renal ditandai dengan hiperfosfatemia dan peningkatan konsentrasi kadar hormon paratiroid serum, peningkatan kadar FGF23, dan aktivitas alkali fosfatase. ${ }^{15-17}$ Pada pemeriksaan radiologis sering kali ditemukan gambaran rickets, penurunan densitas tulang pada pemeriksaan dengan DXA dan pseudofraktur. ${ }^{15-17}$

\section{Tata laksana}

Tujuan terapi anak dengan penyakit ginjal kronik untuk meminimalkan terjadinya osteodistrofi renal adalah untuk mempertahankan kadar kalsium dan fosfat serum dalam batas normal atau mendekati normal, mempertahankan kadar alkali fosfatase dalam batas normal dan mencegah terjadinya hiperparatiroidisme sekunder atau progresifitas hiperparatiroidisme sekunder. ${ }^{15-17}$

Tata laksana osteodistrofi renal meliputi suplementasi vitamin D dan kalsium dan restriksi diet fosfat. Suplementasi kalsitriol dapat mengurangi laju turnover tulang dengan menghambat diferensiasi atau fungsi osteoblas, menurunkan sintesis hormon paratirod dan menghambat degradasi hormon paratiroid di dalam kelenjar paratiroid. Pada osteodistrofi renal, penggunaan binder fosfat oral yang mengandung kalsium berguna untuk mengurangi hiperfosfatemia. Lebih lanjut untuk mensupresi sekresi hormon paratiroid maka dapat diberikan paricalcitol atau ligan sintetik CaSR (cinacalcet hydrochloride). ${ }^{15-17}$

Transplantasi ginjal dapat mengatasi sebagian masalah yang timbuh akibat hiperparatiroidisme sekunder. Namun seperempat anak yang mendapatkan transplantasi ginjal masih ditemukan hiperparatiroidisme sekunder meskipun ringan. Namun yang perlu diperhatikan adalah penggunaan obatobatan glukokortikoid dan obat-obatan imunosupresif seperti siklosporin pada pasien transplantasi ginjal juga dapat menurunkan densitas tulang. ${ }^{15-17}$ 


\section{Kesimpulan}

Menjaga kesehatan tulang seharusnya merupakan bagian yang tidak terpisahkan dalam menatalaksana anak dan remaja dengan penyakit kronik, termasuk pasien dengan penyakit ginjal kronik dalam rangka untuk mengoptimalkan pertumbuhan dan perkembangan anak. Perkembangan teknologi di bidang kedokteran mampu meningkatkan angka survival dan penurunan mortalitas pada anak dan remaja dengan penyakit kronik namun semuanya itu tidak tanpa efek samping yang menyertai. Osteoporosis sekunder pada anak terjadi akibat penyakit kronik yang mendasarinya, sedangkan osteodistrofi renal terjadi akibat hiperparatiroidisme sekunder. Tata laksana terbaik untuk osteoporosis sekunder dan osteodistrofi renal pada anak adalah dengan pencegahan dan semua klinis diharapkan menjadi waspada akan kemungkinan efek simpang terhadap kesehatan tulang. Diagnosis dini dan terapi yang adekuat akan meningkatkan prognosis pada pasien. Klinisi diharapkan juga waspada terhadap meningkatnya risiko osteoporosis pada penggunaan glukokortikoid jangka panjang. Penggunaan glukokorikoid yang rasional akan mengurasi risiko osteoporosis akibat glukokortikoid.

\section{Daftar pustaka}

1. Ward LM. Osteoporosis due to glucocorticoid use in children with chronic illness. Hormone Res 2005;64:209-21.

2. Root AW. Disorders of calcium and phosphorus homeostasis in the newborn and infant. Dalam: Sperling MA, penyunting. Pediatric Endocrinology. Edisi keempat. USA: Elsevier Saunders; 2014.h.237-69.

3. Bishop N, Arundel P, Clark E, Dimitri P, Farr J, Jones G, dkk. Fracture prediction and the definition of osteoporosis in children and adolescents: the ISXD 2013 Pediatric official positions. J Clin Densitom 2014;17:275-80.
4. Mäkitie O. Causes, mechanisms, and management of paediatric osteoporosis. Nat Rev Rheumatol 2013;9:465-75.

5. Kansenty G. The complexities of skeletal biology. Nature 2003;42:316-8.

6. Zhang C, Liu Z, Klein GL. Overview of pediatric bone problems and related osteoporosis. J Musculosklet Neuronal Interact 2012;12:174-82.

7. Shaw NJ. Management of osteoporosis in children. Eur J Endocrinol 2008;159:S33-9.

8. Holick MF, Binkley NC, Bischoff-Ferrari HA, Gordon CM, Hanley DA, Heaney RP, dkk. Evaluation, treatment, and prevention of vitamin D deficiency: an endocrine society clinical practice guideline. J Clin Endocrinol Metab 2011;96:1911-30.

9. Weinstein RS. Glucocorticoid-induced bone disease. N Engl J Med 2011;365:62-70.

10. Uziel Y, Zifman E, Hashkes PJ. Osteoporosis in children: pediatric and pediatric rheumatology perspective: a review. Pediatric Rheumatol 2009;7: 16.

11. Takayanagi H. Osteoimunology and the effects of the immune system on bone. Nat Rev Rheumatol 2009;5:667-76.

12. Comperyrot-Lacassagne S, Tyrell PN, Atenafu E, Doria AS, Stephens D, Giday D, dkk. Prevalence and etiology of low bone mineral density in juvenile systemic lupus erythematosus. Arthritis Rheum 2007;56:1966-73.

13. Boyce AM, Gafni RI. Approach to the child with fractures. J Clin Endocrinol Metab 2011;96:1943-52.

14. Bachrach LK, Ward LM. Clinical review: bisphosphonate use in childhood osteoporosis. J Cin Endocrinol Metab 2009;94:400-9.

15. Wesseling-Perry K, Salusky IB. Chronic kidney disease: mineral and bone disorder in children. Semin Nephrol 2013;33:16979.

16. Wesseling K, Bakkaloglu S, Salusky IB. Chronic kidney disease mineral and bone disorder in children. Pediatr Nephrol 2008;23:195-207.

17. Root AW, Diamond FB. Disorders of mineral homeostasis in children and adolescents. Dalam: Sperling MA, penyunting. Pediatric Endocrinology. Edisi keempat. USA: Elsevier Saunders; 2014.h.797-9. 